\title{
The Cultural Tribes of Public Relations
}

\author{
Greg Leichty \\ Department of Communication \\ University of Louisville
}

\begin{abstract}
This article applies a cultural theory of rhetoric to discourse about public relations. It proposes that 5 distinct cultural voices are recognizable in conversations about public relations. These voices are illustrated in texts that define and critique public relations practice. These competing cultural visions cannot be united into 1 coherent vision. Public relations is a multicultural field that is constituted by this ongoing competitive dialogue.
\end{abstract}

Public relations has been characterized as being plagued by fractured terminology and conceptual confusion (Cropp \& Pincus, 2001) or as a balkanized set of minidisciplines with each contending for disciplinary dominance (Lesly, 1996). This article proposes that the cacophony of voices about public relations is a starting point for characterizing it. This article applies a theory of cultural rhetoric (Douglas \& Ney, 1998; Leichty \& Warner, 2001) to discourse about public relations. Public relations not only contributes to cultural discourse; it also is a site of an ongoing cultural contest. Public relations is a multicultural field that entails an ongoing competition and cooperation among a finite number of cultural voices.

\section{CONCEPTUALIZING CULTURE}

This article synthesizes work from cultural theory in anthropology (Douglas \& Ney, 1998; Ellis, 1998; Thompson, Ellis, \& Wildavsky, 1990) with Fiske's work on the elementary relational structures (Fiske, 1991). It proposes that "plural rationalities" organize social discourse. Douglas and cultural theory scholars (e.g., Douglas, 1996; Thompson, Ellis, \& Wildavsky, 1990) labeled these different rationalities as "cultural biases." A cultural bias is a worldview that cognitively sup-

Requests for reprints should be sent to Greg Leichty, Associate Professor, Department of Communication, University of Louisville, Louisville, KY 40292. E-mail: Gleichty@ louisville.edu 
ports a particular way of organizing social relations (Schwartz \& Thompson, 1990). Each cultural bias has an accompanying set of preferred argument structures or cultural topoi (CT; Leichty \& Warner, 2001). These CT organize discussions of value conflicts in society (Hirschman, 1991). The thesis of this article is that these cultural biases also organize discourse about public relations. This competition of cultural voices appears in histories of public relations, accounts of professional practice, estimates of public relations's future trajectory, and normative prescriptions for public relations practice.

Of culture, Douglas (1997) recently wrote, "Think of culture as essentially a dialogue that allocates praise and blame. Then focus particularly on the blame" (p. 129). Cultural theory proposes that "culture" is an ecosystem inhabited by a finite number of ways of life (Thompson et al., 1990). Culture emerges in the contentious conversation among the ways of life. A way of life consists of a preferred pattern of social relations and a cultural bias or set of shared values and beliefs about people and the natural world (Thompson et al., 1990). These configurations of belief and social relations are "reciprocal, interacting and reinforcing. Adherence to a certain pattern of social relationships facilitates a distinctive way of looking at the world; adherence to a certain worldview legitimizes a corresponding type of social relations" (Thompson et al., 1990, p. 1). A way of life is viable only as long as its cultural bias and its pattern of social relationships are compatible with each other. For the remainder of the article, "a cultural voice" will refer to instances when the premises of a "cultural bias" are articulated in argument. In addition, a "cultural tribe" will refer to an "interpretive community" that shares a particular cultural bias.

Cultural theory posits that the social construction of reality operates within set limits (Douglas, 1996). There are only five enduring voices in the cultural competition; only fatalism, egalitarianism, hierarchy, autonomous individualism (AI), and competitive individualism are coherent enough to attain long-term viability (Thompson et al., 1990). A cultural bias is an internally consistent template that structures human relationships. The core propositions of each cultural bias are also argument structures. A topos or topic structure is a general theme that can be used to develop persuasive arguments on a wide set of topics. A cultural topos is a systematic argument that reinforces a preferred pattern of social relationships (Leichty \& Warner, 2001). Each cultural voice has a core set of CT.

Table 1 summarizes the core CT of the five cultural voices. The most fundamental arguments of each cultural voice are its assertions about "nature" and "human nature." "That's the way the world is" or "That's the way people are" are final arguments put forward to quell further disputation (Douglas, 1996). These beliefs about reality are associated with a supporting value imperative, a decision-making principle, a justice principle, and an activity principle. The cultural voices fundamentally disagree with one another in their assertions about reality and the preferred structure of social relations. The topoi of the cultural voices are ordered from left to right, from 
TABLE 1

Cultural Topoi Compared

\begin{tabular}{|c|c|c|c|c|c|}
\hline $\begin{array}{l}\text { Foundational } \\
\text { Beliefs }\end{array}$ & Fatalist Topoi & Egalitarian Topoi & Hierarchical Topoi & $\begin{array}{c}\text { Autonomous } \\
\text { Individualist Topoi }\end{array}$ & $\begin{array}{c}\text { Competitive } \\
\text { Individualist Topoi }\end{array}$ \\
\hline Nature & $\begin{array}{l}\text { Nature is } \\
\text { capricious and } \\
\text { unpredictable. }\end{array}$ & $\begin{array}{l}\text { Nature is fragile; its } \\
\text { equilibrium is } \\
\text { precarious. }\end{array}$ & $\begin{array}{l}\text { Nature is bountiful, if } \\
\text { it has a gardener. }\end{array}$ & $\begin{array}{l}\text { Nature is benevolent, } \\
\text { if you match } \\
\text { yourself to it. }\end{array}$ & $\begin{array}{l}\text { Nature is bountiful } \\
\text { and resilient. }\end{array}$ \\
\hline Human nature & $\begin{array}{l}\text { Human nature is } \\
\text { capricious and } \\
\text { unpredictable. }\end{array}$ & $\begin{array}{l}\text { Human nature is good, } \\
\text { but social inequality } \\
\text { corrupts it. }\end{array}$ & $\begin{array}{l}\text { Human nature is bent, } \\
\text { but discipline can } \\
\text { straighten it. }\end{array}$ & $\begin{array}{l}\text { Human nature is } \\
\text { ignorant, but it can } \\
\text { be enlightened. }\end{array}$ & $\begin{array}{l}\text { Human nature is } \\
\text { self-seeking, but } \\
\text { competition } \\
\text { channels it } \\
\text { productively. }\end{array}$ \\
\hline Value imperative & $\begin{array}{l}\text { Accept reality. } \\
\text { Do not try to } \\
\text { change it. }\end{array}$ & Seek equality. & Seek order. & Seek enlightenment. & Seek liberty. \\
\hline Decision principle & Let fate decide. & Seek consensus. & $\begin{array}{l}\text { Legitimate authority } \\
\text { decides. The chain } \\
\text { of command } \\
\text { implements. }\end{array}$ & One person, one vote. & Let the market decide. \\
\hline Activity principle & $\begin{array}{l}\text { Take what comes } \\
\text { your way. }\end{array}$ & Do it for love. & $\begin{array}{l}\text { Practice until you are } \\
\text { good at it. }\end{array}$ & $\begin{array}{l}\text { If you do it, avoid } \\
\text { coercive } \\
\text { entanglements. }\end{array}$ & $\begin{array}{l}\text { Do whatever you do } \\
\text { best. }\end{array}$ \\
\hline Justice principle & Que sera sera. & $\begin{array}{c}\text { From each according } \\
\text { to ability, to each } \\
\text { according to need. }\end{array}$ & $\begin{array}{l}\text { Give and receive } \\
\text { according to rank. }\end{array}$ & $\begin{array}{l}\text { To each an equal } \\
\text { portion. }\end{array}$ & $\begin{array}{l}\text { To each in proportion } \\
\text { to her contribution. }\end{array}$ \\
\hline
\end{tabular}

Note. From Handbook of Public Relations (pp. 67-74), by R. L. Heath (Ed.), 2000, Thousand Oaks, CA: Sage. Copyright 2000 by Sage Publications. Adapted with permission. 
the simplest to the most complex, and in terms of the degree of strategic calculation required to sustain each type of social relations (see Fiske, 1991).

According to cultural theory, the five ways of life constitute a cultural ecosystem. Each way of life defines itself relative to its competitors, and each way of life competes for adherents. Each way of life waxes or wanes relative to the success that its topoi have in predicting, interpreting, and managing events (Thompson et al., 1990). CT have great durability in cultural debates, even extending over several centuries (Hirschman, 1991). However, societal events can increase the allure of a cultural voice and diminish the potency of competing cultural voices. The terrorist attacks of September 11th strengthened the appeal of hierarchy (i.e., national security). Likewise, the collapse of Enron gave some new impetus to egalitarian initiatives like campaign finance reform. These gains have been at the expense of competitive individualist (CI) topoi that dominated discourse during the 1990s stock market boom.

Each cultural bias provides lenses for interpreting the world. Each way of life clearly sees what the other ways of life do not see. As with optical illusions, one can only see one thing at a time. To see differently, one must change lenses. Even when they agree on nouns and verbs, the ways of life disagree on adjectives and adverbs. CIs celebrate the elegant efficiency in markets, but egalitarians bemoan wasteful and vindictive conspicuous consumption that markets enable.

Cultural theory proposes that each way of life is incomplete. Thompson et al. (1990) wrote, "Each way of life needs each of its rivals, either to make up for its deficiencies, or to exploit, or to define itself against. To destroy the other (way of life) is to murder the self' (p. 4). A way of life contains contradictions and pathologies (Ellis, 1998). The ways of life compete and give form to culture. Each group develops its own set of compromises and social institutions (Fiske, 1991). One voice may dominate discourse or two voices may form a dominant coalition. The remaining voices tend to be ignored or marginalized. Representative democracy is a coalition of cultures in which each voice is articulated somewhere in the differentiated institutions of representative democracy (Wildavsky, 1987).

The cultural voices also collaborate. Two ways of life may share values and preferred means. They may support the same means for different reasons. Hierarchical advocates endorse school uniforms because they symbolize order, but egalitarian advocates embrace uniforms because they mute displays of social inequality (Leichty \& Warner, 2001). Cultural alliances and oppositions shift as historical circumstances change. For culture, there "is no final equilibrium point. Change is inherent in the different competencies and biases of different cultures" (Lockhart, 1997, p. 99).

The hierarchical and egalitarian voices privilege the"common good" and disparage the opportunism of CIs and fatalists. Egalitarians and individualists dislike the regimentation of hierarchical culture. Individualist and hierarchical voices defend the virtues of social inequality. The fatalist voice can be engaged in alliances 
of evasion and passive resistance. Fatalists may help individualists evade the organizing impulses of hierarchy or passively assist hierarchy in preserving the status quo against the attacks of egalitarian reformers (i.e., the silent majority).

Groups make difficult tradeoffs between the values embedded in the different cultural biases when they decide how to allocate scarce resources (Tetlock, 2000; Tetlock, Kristel, Elson, Green, \& Lerner, 2000). Fiske and Tetlock (1997) noted that people experience anxiety, ambivalence, or outrage when they encounter such trade-offs. For instance, an explicit discussion about how much an HMO should be required to spend on experimental medical treatments to save one individual's life causes us discomfort. Ordinarily, it is taboo to discuss such topics. To put a dollar value on human life offends our sensibilities (Tetlock et al., 2000).

\section{THE CULTURAL TRIBES OF PUBLIC RELATIONS}

The CT perspective applies in any context where people argue about how they should organize their social relationships (Douglas \& Ney, 1998). This article illustrates how these cultural voices animate discussions about the nature of public relations. The article employs a mix of discourse exemplars from public relations scholarship and professional publications that are available to public relations practitioners, as well as texts that criticize existing public relations institutions and practices. This approach emphasizes the similarities and continuities between these different discourse genres. It also attempts to demonstrate that the $\mathrm{CT}$ framework has heuristic value: It is flexible and is applicable to discourse in each domain.

A "rational text" uses a consistent set of topoi in its arguments. However, some texts are internally inconsistent (Adams, 1995). A person may also believe that one domain (i.e., family life) fits one model, but that another domain (i.e., professional life) fits another model (Fiske, 1991). The cultural voices also may agree on an ideological point. One sometimes must scrutinize arguments at a microlevel before the differences in underlying topoi become evident (Tetlock, 2000). The cultural voices also differ in how frequently they voice their concerns (e.g., fatalism). Mapping the subterranean features of argument also requires persistent attention to what remains unsaid.

\section{The Fatalist Voice}

Fatalist culture is indifferent to disputes about the nature and obligations of public relations. The other cultural camps often disparage it. The fatalist tribe has low expectations for public relations as a whole. The fatalist voice is underrepresented in the discourse of professional associations. It seldom argues for or justifies the public relations function. Fatalist culture does not debate these issues because it perceives that public relations practitioners lack the power to order their situation. The 
factors that really affect public relations practice lay beyond practitioners' control (i.e., practitioners have an external locus of control). It offers few visions about the future of practice. Popular culture portrayals of fatalistic public relations depict public relations practitioners as obsequious, cynical, isolated, and unfulfilled (Miller, 1999).

The fatalist voice does not proselytize, but it is a voice of resistance (Douglas, 1997). It speaks through inattention and excuses for inaction. It resists the exhortations to engage in programmatic action. When asked to support a program to enhance the influence of public relations, the fatalist voice demurs because the proposed course of action is futile (Hirschman, 1991). Collective action will not make a significant difference.

Closed-ended survey questions seldom find the fatalist voice. However, in-depth interviews and ethnographic observation can locate the fatalist voice as they probe practitioners' daily routines (Sriramesh, 1996; Sriramesh, Kim, \& Takasaki, 1999). It also becomes audible when outsiders appraise the discipline or when professionals confide about their disillusionment with the profession (Seitel, 1998). The fatalist voice also murmurs in despotic environments where practitioners perceive that unpredictable and capricious forces determine their fates.

Celebrity public relations can be unpredictable and capricious. Publicity becomes an end in itself because it creates a celebrity premium that people are willing to pay for (Rein, Kotler, \& Stoller, 1997). However, "high visibility public relations" can be a high-stakes, zero-sum game. The number of celebrities who can be created and maintained is rather finite and inelastic. Rein et al. wrote, "The more popular the sector, the more violently a person's celebrity status will fluctuate" (p. 315). The fortunes of public relations promoters are driven by the fickle hand that determines who is hot and who is not.

Even if celebrity public relations is successful, "the bad news is that publicists are often not included as an important player at the center of the visibility marketing process and are not financially rewarded at the same level as agents and managers" (Rein et al., 1997, p. 273). Indeed, the celebrity industry usually maintains a low profile. The ghostwriter selectively sorts the facts of a life and creates a celebrity narrative that cannot publicly acknowledge the writer's contribution.

The practitioner also must cope with the caprices of temperamental and neurotic celebrities. Handholding is listed as one of the essential duties of the celebrity promoter because

Celebrities often need reassurances and smiles of pseudo-intimacy. ... In a world in which it is very hard to evaluate with any precision what you're doing from day to day, a hand-holder supplies the important services of confidence-building and ego maintenance. (Rein et al., 1997, p. 278)

Moreover, creating a celebrity often creates an uncontrollable ego that "often grows into cockiness and arrogance" (Rein et al., 1997, p. 307). Rein et al. re- 
marked that these tendencies often are cultivated by the "entourages of obsequious support personnel that surround the celebrity" (p. 307).

Press agentry is often characterized as a residue of public relations practice from a different era that has been replaced by more productive and ethical public relations models (e.g., J. E. Grunig \& Hunt, 1984). However, the chroniclers of "high visibility" declared that "celebrity worship and visibility-seeking is in an explosive growth phase" (Rein et al., 1997, p. 335) that is spreading to all sectors of society. The fatalist voice emerges when "high visibility public relations" becomes a capricious zero-sum game.

The fatalist voice also appears in organizational public relations. Fatalist culture does not consider public relations to be a self-defining and self-regulating system. Public relations is whatever top management says it is: a marginal organizational function that is not seated at the management roundtable. For instance, public relations may be subordinated to another organizational function. Kotler (1994) observed, "PR has generally been treated as a marketing stepchild, an afterthought to more serious promotional planning" (p. 677).

Within public relations research, a great deal of attention has been devoted to the study of the role that practitioners play within the organization. The prevailing consensus is that most public relations practitioners work as technicians rather than as managers (Broom \& Dozier, 1986). Dozier (1992) argued that, unless a public relations department has at least one practitioner in a management role, the organizational influence of public relations will be minimized. In such environments, one might expect to find a fatalistic worldview. Leichty and Springston (1996) found that one of their five public relations role clusters endorsed aspects of the fatalistic voice. This group, which Leichty and Springston labeled as externals, thought the public relations department was peripheral to the communication flows in the organization. They also thought the public relations department had little influence or power. This type of practitioner was usually the only full-time public relations professional in the organization. These practitioners had few opportunities for professional advancement within their organizations.

Some aspects of the fatalist voice also appear in the Personal Influence model of public relations (Sriramesh et al., 1999). The personal influence model was defined as "a quid pro quo relationship between the public relations practitioner and strategically placed individuals such as government regulators, media persons and tax officials" (Sriramesh et al., 1999, p. 272). The personal influence model is most likely to be employed in those nations in which public opinion is not well articulated in the media and where governmental officials are the most important audience for public relations messages (Taylor \& Kent, 1999).

Sriramesh's (1996) ethnographic account of public relations practice in Southern India found that public relations practitioners spent much of their time ingratiating themselves with powerful people. Practitioners provided small favors to gain personal favor and influence with powerful targets. Personal influence activities 
included "hospitality, giving gifts and brokering of influence, to build lasting friendships with strategically placed individuals with the aim of seeking favors in return" (Sriramesh, 1996, p. 186). Most of the practitioners in his sample had public relations titles, but had little power to influence policy decisions in their organizations. Sriramesh asserted that practitioners desired professional autonomy, but "most were reluctant to express this to their superiors because they thought that it would not make any difference" (p. 187). I propose that the personal influence model was most likely in social contexts where there is a high deference to authority by subordinates and an intolerance of subordinates' viewpoints by superiors. This analysis is consistent with the findings of research in other countries, such as Romania, that are emerging from a totalitarian past (Turk, 1996). Wherever low practitioner power and a capricious environment combine, personal influence will be cultivated as a means of coping.

The fatalist view of public relations also appears in the disinterested assessments of outsiders. Peter Drucker, the renowned management consultant, opined:

There is no public relations. There's publicity, promotion, advertising, but "relations" by definition are a two-way street. And the more important job and the more difficult is not to bring the business and execution to the outside but to bring the outside to terribly insulated people. (Seitel, 1998, p. 10)

Drucker said public relations professionals fail to "tell the truth to management. Public relations people today don't do that because they are scared; because the people they work for don't like to hear what they don't want to hear" (p. 15).

Several developmental trajectories lead to a fatalistic view of public relations practice. One trajectory is the route of dashed expectations. A public relations professional may begin with an idealistic vision of how to practice public relations, but become cynical when these expectations are dashed. Drucker recounted the case of Paul Garrett, the first public relations officer for General Motors:

Paul was a very bitter man. He and I talked about it after he retired. Paul Garrett came out of journalism. He wanted to build a proper public relations department to bring to GM what the outside was like. He would have been very effective. But GM wouldn't let him. They wanted him to be a publicity man. (Seitel, 1998, p. 10)

A fatalistic viewpoint may develop when a practitioner encounters a chaotic environment that subverts normal public relations practice. Kohn (2000) argued that among high-tech companies, the quest to prop up a company's stock price often subverted public relations values. She wrote, "When the stock price was up, all of us were heroes. When it was down, we were scapegoats" (p. 28). When the stock price starts to drop, "strategy for the most part, goes out the door. Forget setting goals and objectives and creating strategies and tactics. Forget the 
well thought out public relations plan that was created and approved at the beginning of the year" (p. 28). She ultimately faced a stark choice about whether to embrace a fatalistic view of public relations. "We can either become 'yes' people and go with what we know is fundamentally wrong, or move on. I have chosen to move on" (p. 30). Kohn did not ultimately embrace fatalism, but she clearly understood its developmental trajectory.

A practitioner may also embrace fatalist topoi after a precipitous career decline. Meyer (1996) embodied this attitude when he encouraged job hunters in public relations to combine a sense of humor with a stoic attitude. "You are in an absurd, outlandish often flamboyantly irrational situation. ... It can break your heart and your mind if you expect it to be much better than that" (p. 15). The job seeker should consider himself or herself to be a hunk of meat. He observed:

You will find yourself changing from one kind of meat to another kind with bewildering speed. ... Try not to let it get you down too much. It's not you, you're not the problem; the headhunter is occupied elsewhere. A new slab of meat has been found.

(Meyer, 1996, p. 15)

He lamented, "Age discrimination is nearly universal, absolutely nothing is done about it; it's hard to see what could be done about it" (Meyer, 1996, p. 18).

Meyer (1996) justified his fatalism, declaring, "While these are not fun things to write, they're a part of what I now believe. And though admitting the facts doesn't itself solve problems, it beats living in a fantasy" (p. 16). He concluded with the ironic fatalist observation that one's luck can turn.

And then out of the blue, I got an unsolicited call from a headhunter I'd never heard of and never tried to contact. Weeks later I not only was back at work, but in the best working environment I'd ever experienced, in charge of a communications department bigger than any I'd ever managed before. So: Don't give up. You never really know. (Meyer, 1996, p. 18)

Fatalist culture shrugs off the insults of hierarchical culture, the malign neglect of individualist culture, and the proselytizing fervor of egalitarian culture. It is better to face some of the unpleasant facts of public relations practice than it is to live in a fantasy world. It is best to persevere through the bad and to enjoy the good when it comes.

\section{The Egalitarian Voice}

The egalitarian voice is a prophetic voice. It animates activists who seek to reduce social inequality. It has manifested itself in the abolitionists, the muckrakers, and many social movements in the 20th century (Ellis, 1998). Although there is a 
fledgling in-house egalitarian public relations voice, this voice usually speaks from the periphery of public relations. It prefers to critique the establishment rather than to negotiate with it (Douglas \& Wildavsky, 1982). Its voice animates conversations about the nature of public relations. Unflattering egalitarian characterizations of public relations are a feature of popular culture's depictions of public relations (Miller, 1999). Its stark characterizations of public relations practice energize the cultural voices of the dominant coalition to declare, "Public relations isn't at all like that" (e.g., Seitel, 2000).

Egalitarian critics of public relations accuse it of distorting communication and undermining the processes of participatory democracy (Berger, 1999; Ewen, 1996; Gandy, 1992). The work of Stauber and Rampton (i.e., Rampton \& Stauber, 2001; Stauber \& Rampton, 1995), two investigative journalists, is a sustained and acerbic critique of corporate public relations. Their first book, entitled Toxic Sludge is Good for You, utilized standard egalitarian topoi to characterize corporate public relations.

Stauber and Rampton (1995) accused public relations of having an antidemocratic bias. "This contemptuous attitude toward democracy is the heritage of Edward Bernays, the father-philosopher of public relations who saw corporate 'engineering of consent' as a way to eliminate the "chaos' in democratic society" ( $\mathrm{p}$. 202). However, democracy is "chaotic, messy and unpredictable — and most bothersome of all to PR practitioners, it often produces decisions that their clients are unable either to predict or control" (p. 203). Authentic democracy "must be lived daily, its values woven into the fabric of society. ... Democracy is not like fast food. It can't be standardized, mass-produced, made predictable and convenient" (p. 204).

Public relations threatens democracy because "raw money enables the PR industry to mobilize private detectives, attorneys, broadcast faxes, satellite feeds, sophisticated information systems and other expensive, high-tech resources to out-maneuver, overpower and outlast true citizen reformers" (Stauber \& Rampton, 1995, p. 14). However, corporate public relations has an Achilles heel. "Today's opinion industry is a powerful giant, but like Goliath, it is a giant with a fatal weakness. When the public is educated about its techniques, it often loses its ability to mislead and manipulate" (p. 16).

According to the egalitarian voice, public relations operates by stealth, because it proposes tradeoffs relating to the value of human life that it cannot defend in public (Fiske \& Tetlock, 1997). The egalitarian voice searches for a treacherous tradeoff to publicize and thereby mobilize outrage. This provides riveting entertainment for the mass media and gives public relations's dominant coalition indigestion (e.g., Holt, 1995). Stauber and Rampton (1995) took this tack in pointing to the inherent corruption of corporate public relations. "The need to maximize profit drove antifreeze makers to hire a PR spy so they could fight a law that would save children's lives at a price of only two cents a gallon" (p. 203).

Unmasking public relations's deceits is difficult because public relations practitioners conceal their work. Rampton and Stauber (2001) took aim at public rela- 
tions's cultivated use of third-party expert endorsements. The guiding mantra for public relations practitioners was to "put your words in someone else's mouth. The 'someone elses' become Potemkin authorities, faithfully spouting the opinions of their benefactors while making it appear that their views are "independent"' ( $p$. 17). This approach "offers camouflage, helping to hide the vested interests that lurks behind a message" (p. 19). This works because journalists have become dependent on the information subsidies of press releases and video news releases provided by industry and government sources (Gandy, 1992).

Public relations's egalitarian critics are particularly critical of "pseudo-grassroots" movements. "Astroturf" organizing deprives social movements of their natural advantage in public debates: public skepticism about the intentions of corporate interests. "Recognizing that industry lacks credibility on environmental issues, industry's public relations modus operandi often is to create front groups to advocate its interests—-sometimes well-cloaked, other times thinly veiled, and always with Orwellian names" (Fulwood, 1996, p. 10). Front groups enable "corporations to take part in public debates and government hearings behind a cover of community concern" (Beder, 1998, p. 20). "Astroturf public relations" confuses the public as to who the heroes and the villains are. This sows doubt about the authenticity of the egalitarian voice and makes it difficult to mobilize outrage.

In recent years, the egalitarian voice has begun to articulate an affirmative vision of public relations that embraces a communitarian ethic (Leeper, 2001). Public relations scholars have been at the head of this effort (e.g., Banks, 2000; Hon, 1995; Kruckeberg \& Starck, 1988). The affirmative egalitarian vision proposes to reform corporate public relations along egalitarian lines and to expand the definition of public relations to include the organizing activities of activist groups.

The reformers propose to rebuild public relations on the usable parts of public relations practice. Kruckeberg and Starck (1988) asserted, "Community relations is the paradigm case of public relations" (p. 23). They proposed that public relations should embrace community building.

Interest in community welfare, social order, and progress can be addressed by public relations practitioners. As a social center, through a concern for art and a concern for community play, the organization can help to enhance community. Practitioners can help the community share aesthetic experience, religious ideas, personal values, and sentiments. (Kruckeberg \& Starck, 1988, p. 116)

Practitioners will not only do advocacy, but also will foster communication that "offers an immediate enhancement of life, which can be enjoyed for its own sake" (Kruckeberg \& Starck, 1988, p. 115).

The feminist critique of public relations is the most developed egalitarian effort to transform corporate public relations (Creedon, 1993; L. A. Grunig \& Toth, 2001; L. A. Grunig, Toth, \& Hon, 2000; Hon, 1995; Kern-Foxworth, 1994; Toth, 
2001). Feminist research has identified structural changes that are necessary to make public relations a more equitable profession, including making public relations's body of knowledge more inclusive and gender sensitive. These inquiries have sensitized researchers to the inequitable power arrangements in gendered relationships and have increased the discipline's sensitivity to the experiences of public relations practitioners (Toth, 2001).

Although some practitioners have worried that the increasing proportion of female practitioners threatens the organizational status of public relations, feminist theorists believe that "women's emergence in public relations is an opportunity for a more responsible and effective practice" (L. A. Grunig et al., 2000, p. 50). The discipline will be transformed as students and practitioners come to embrace feminist values (e.g., cooperation, valuing relationships, altruism). The classroom may be the

ideal setting in which to consider that the development of personal feminist values that have implications for public relations practice. Such consideration would benefit all students and may be an important step toward realization of our aspirations for a practice that is truly professional, truly ethical and truly effective. (L. A. Grunig, Toth, \& Hon, 2000, p. 63)

Explicitly embracing feminist values should "help define the field and, in particular, clarify its purposes. Those purposes - such as reinstitution of community, the development of relationships, and the resolution of conflict-will be grounded in the character of those who work in public relations" (L. A. Grunig et al., 2000, p. $65)$.

Egalitarian theorists insist that public relations must embrace diversity for both moral and practical reasons (Banks, 2000; Hon \& Brunner, 2000). As every domain of public relations practice becomes more diverse, "practitioners and educators must become more sensitive to this environmental change by enacting diversity as a concern relevant to their professional lives and by responding to it interactively" (Banks, 2000, p. 115). Instead of

seeking similarity and harmony, we need to recruit people and pursue ideas that challenge the status quo. We should not just seek out identifiable minorities, but also people who have demonstrated a sensitivity to cultural diversity and a commitment to helping others become responsive to it. (Banks, 2000, p. 117)

The affirmative egalitarian vision of public relations also seeks to expand the definition of public relations. The activities of activist groups are also within the boundaries of public relations. Smith (1997) argued, "The exclusion, or misrepresentation, of activist organizations in the scholarly and pedagogical literature limits our understanding of public relations" (p. 2). The distinction between or- 
ganizational public relations and social movements is a false dichotomy. Activists must organize to pursue their goals. Once they do, they also "face challenges that require public relations programs" (Smith \& Ferguson, 2001, p. 294). The activist organization must compete with other activist organizations for attention and resources to maintain its membership. "One of the realities of activism is that simple survival requires a great deal of time and energy" (Smith \& Ferguson, 2001, p. 294).

Critical theorists criticize public relations research because it subsidizes "commercial and state communications at the expense of other segments of the population" (Karlberg, 1996, p. 263). Public relations research has "privileged—or subsidized-certain segments of the population and marginalized others to the periphery of public discourse" (p. 264). Public relations's body of knowledge is inaccessible to most people. Only commercial and state entities have the professional experience and material resources to apply the body of knowledge. Public relations scholars should develop knowledge that equips ordinary citizens to enter into public discourse. "Public communication skills and resources must be extended to all segments of society if communication symmetry is to be recognized" (p. 273). Researchers should focus on the "types of communication practices that are within the reach of resource-poor segments of society" (p. 273).

Holthauzen (2000) argued that "public relations can contribute to grassroots democracy through activism and radical politics" (p. 93). Pointing to the inevitable contradictions within public relations's ideology, "This perspective opens the door for public relations practitioners to act as community activists, an approach that is not only radical but also ethical and desirable" (p. 99). Enlarging the scope of public relations will require dramatic shifts in public relations education. "The field's case studies, texts and research give preference to public relations as a management function of capitalist organizations, including state organizations" (p. 100). This will involve some conflict among practitioners, as "public relations practitioners line up on opposite sides of the trenches, but so do legal practitioners, marketing experts, and many other professionals in everyday life" (p. 100).

The postmodern environment will be so turbulent that the predictive tools of social science will be of little use. "Hot issue publics and the media skills of activists call into question the ability to deal proactively with activists" (Holthauzen, 2000, p. 103). Fluid interactions between organizations and publics will replace issues-management. For the postmodern version of public relations, it will "be the responsibility of the public relations function to create opportunities for dissent, for opening up debate without forcing consensus, to create possibilities for change" (Holthauzen, 2000, p. 105).

Some scholars have investigated the public relations dimensions of egalitarian social movements (e.g., Hon, 1997; Kern-Foxworth, 1992). Kern-Foxworth examined how Martin Luther King mobilized a massive social movement to attack segregation. She noted, 
In his various campaigns King identified his audiences carefully and methodically. ... King drew from all of the major reference groups of society, academy and church. These were his publics and he used everyone available to reach each one with his self-proclaimed theme of the "American Dream." (Kern-Foxworth, 1992, p. 289)

King selected his campaign sites with an eye toward dramatizing the brutality of segregation. He selected Birmingham, Alabama because it epitomized the worst of segregation. He went to Birmingham to "lead demonstrations there until 'Pharaoh lets God's people go"” (Kern-Foxworth, 1992, p. 291). Even when he sat in jail, King seized the public relations moment. "Never missing an opportunity to give the movement momentum, King chose this time to write a letter" (Kern-Foxworth, 1992, p. 292). More than a million copies of the letter, A Letter From the Birmingham Jail, were mailed to churches, magazines, and politicians. More than 250 journalists from all over the world converged on Birmingham to cover the campaign (Kern-Foxworth, 1992).

Because it lacks financial resources and power, the egalitarian voice must be opportunistic and tactical. As Alinsky (1971) put it, "Tactics means doing what you can with what you have" (p. 126). As opportunities present themselves, tactics are developed. The real resource "is the enemy's reaction. ... The enemy properly goaded and guided in his reaction will be your major strength" (p. 136). Moreover,

Tactics are not the product of careful cold reason, they do not follow a table of organization or plan of attack. Accident, unpredictable reactions to your actions, necessity and improvisation dictate the direction and nature of tactics ... the tactic itself comes out of the free flow of action and reaction. (Alinsky, 1971, p. 165)

The egalitarian voice differentiates between strategic public relations and public relations tactics (Alinsky, 1971). It is anxious that the strategic use of public relations by large organizations subverts participatory democracy, but the egalitarian voice embraces public relations tactics as essential tools for promoting social change. In the parallel egalitarian movement of public journalism, publicity emerged as an essential tool for mobilizing action and developing community (Peters, 1999). Rejecting "strategy" and embracing "tactics" is faithful to the underlying egalitarian tendency to value spontaneity in action (Leichty \& Warner, 2001).

Although it is often excluded from the debates of public relations's dominant coalition, the egalitarian voice has profoundly influenced public relations practice. It makes the cultures of the dominant coalition nervous. As a gadfly culture, the egalitarian voice is always ready to sting. In its affirmative form, it seeks to make public relations work for the common good. It is not yet a part of public relations's dominant coalition, but its influence is increasing. 


\section{The Hierarchical Voice}

The hierarchical voice has long been a member of public relations's dominant coalition, along with the CI voice. It frequently appears in accounts of public relations history and practice. It aims to improve the status of public relations and to institutionalize public relations as a core management function. It has used public relations history to enhance the discipline's status (Pieczka \& L'Etang, 2001). Its version of public relations history depicts a process of steady evolutionary progress. Despite its origins in the tawdry practice of press agentry, public relations has come of age as a knowledge-based discipline (Cutlip, 1994; J. E. Grunig \& Hunt, 1984; Seitel, 2001).

Edward Bernays consistently articulated the hierarchical voice. Bernays portrayed public relations counselors as societal psychotherapists. "Society has become more complex and its processes have been speeded up over the last few centuries. The rate of progress of the many forces that make up society has been uneven with consequently increased maladjustment and tension" (Bernays, 1952, p. 3). Bernays wanted to solve irrational communication problems. "Maladjustments in many fields - commerce, industry, religion, and government — are based upon the misunderstanding of realities and communications processes. ... Conflict that is based on misunderstanding, ignorance, and apathy is unnecessary and wasteful" (p. 9).

Bernays (1952) saw public relations as "a vital tool of adjustment, interpretation, and integration between individuals, groups and society" (p. 7). Public relations "is vitally important today because modern social science has found that the adjustment of individuals, groups, and institutions to life is necessary for the well-being of all" (p. 3). It is an activity "that makes competition, another factor of our society, more efficient and effective" (p. 7). The public relations counselor must overcome the ignorance of clients and publics. Although the "highest level of adjustment is reached at the point of enlightened self-interest. The public relations counsel must ensure that such enlightenment prevails [italics added]" (p. 4).

Bernays recognized that much of public relations practice fell short of the hierarchical ideal. He attributed this imperfection to the lack of controlled barriers to entry into the profession. "There are too few trained and skilled practitioners. In the early years of the profession, many crowded in who had little specialized knowledge, aptitude or experience" (Bernays, 1955, p. 6). Throughout his life, Bernays championed the cause of licensing public relations practitioners. He thought licensing would help secure public relations's boundaries and exclude unscrupulous and incompetent practitioners. Bernays remained optimistic about public relations's prospects and projected a rising curve of disciplinary growth and maturation (Bernays, 1952). Life in the democratic age was vexing, but with advice of public relations counselors, leaders could navigate these rapids with confidence. 
The hierarchical preference for dispassionate expertise also appeared in Hill's (1993) account of how Hill and Knowlton operated. Hill was proud that his firm was the first to

1. Offer a broad range of specialized public relations services.

2. Apply cost accounting and budgeting procedures to agency work.

3. Develop an international presence in public relations.

4. Create a professional research division.

He celebrated the breadth and depth of his professional staff by reciting their years of public relations experience, their educational pedigrees, and their international experiences. Displaying a faith in the hierarchical themes of content specialization and hierarchical integration, he wrote, "Only by such a variegated grouping of education, experience, talent and linguistic capabilities can a large public relations firm meet the requirements of its clients" (Hill, 1993, p. 148).

Hill (1993) portrayed public relations work as a dignified enterprise. He believed that teamwork among experts would "replace the lone-wolf operator-the 'Big I Ams' — as an important factor in the public relations business" (p. 144). He insisted that his firm not solicit business because "we have tried over a period of three and a half decades to build a reputation for high standards of service" (Hill, 1993, p. 148). Referrals from existing clients provided the needed business. In a tone similar to current manifestos of relationship marketing (e.g., Peppers \& Rogers, 1997), Hill (1993) opined, "The relations of public relations firms with their clients ordinarily is intimate and deeply immersed in policies and activities" (p. 149). He wrote, "Fortunately, the public relations counseling business is unlike advertising in that among the top-grade firms the shifting of accounts from one firm to another is indeed a rarity" (Hill, 1993, p. 149).

Philip Lesly $(1984,1991,1996)$ represented a more pessimistic strain of the hierarchical viewpoint. Surveying the rise of egalitarian movements in the United States, Lesly (1984) counseled executives on how to prevail over the forces of anarchy. Lesly was pessimistic about the possibilities for societal adjustment and integration. He believed that egalitarianism was a rising menace that needed to be neutralized.

Lesly (1984) asserted, "The first responsibility of an executive is to create and maintain orderly procedures. ... The effective manager is naturally repelled by disorder and threats to smooth operations" (p. v). He complained that the climate of public opinion was "an attack upon leadership. It presumes that all organizations are suspect and that the leaders of those organizations are probably scoundrels or oppressors" (p. vi). Lesly feared that hierarchy would be "replaced by a tyranny of the crowd, in which the assertiveness of groups of people prevents any orderly functioning" (p. 12). Executives must defend their organizations. "It is evident on all sides that it is those who defy authority disclaim any responsibility for their in- 
surgence; and it is the established institution that needs to defend itself against siege" (Lesly, 1984, p. 4).

Lesly (1996) also lamented the "balkanization" of public relations. Public relations was increasing in its scope, but

its power is being dissipated by competition for the spotlight among its varied practitioners. Each function of the field ... is seeking to define itself as public relations, rather than recognizing that it is only one element in a very broad field. (Lesly, 1996, p. 41)

In defining the field, one should "stress the gestalt of public relations rather than the segment. Give primacy to the really vital functions and base everything in public relations education to breadth and depth" (Lesly, 1996, p. 44). Lesly preferred a far-sighted systems-oriented perspective.

The hierarchical voice for public relations shares the common desires for (a) distinct boundaries for defining public relations, (b) a definitive body of knowledge that hierarchy can apply, and (c) regulative mechanisms to defend the boundaries of public relations (i.e., keep charlatans and unqualified persons out of the profession).

The stock arguments of the hierarchical voice have been quite consistent. Some current appeals echo Bernays (1952) in remarkable ways. For instance, Botan (1989) argued that

if an applied social science approach is taken, public relations can develop a body of theoretic knowledge that meets and distinguishes the practice of public relations from the craft of the communication technician. ... Such a body of knowledge ... is the foundation stone on which public relations can develop more and more professionalism. (p. 107)

A standardized body of knowledge would guide public relations practice, help standardize public relations curricula, generate respect for the profession, and repel the epitaphs of "public relations flack." A body of knowledge would ease hierarchy's fears about the discipline's foundations. Many believe that public relations theory and scholarship are steadily progressing toward this goal. The aim is to integrate relevant knowledge into a systemic and predictive theory. For instance, crisis public relations is moving from crisis communication toward anticipatory models of crisis management (Coombs, 1999; Olaniran \& Williams, 2001).

Hallahan (2001) saw a similar movement in media planning. Where media planning once required little planning, the current situation is "starkly different. The sheer number of publicity outlets has expanded, increasing the direct costs to provide materials and making it difficult to approach every potential outlet effectively" (p. 461). In this more complex media landscape, public relations practitioners need to "practice and think about media broadly and strategically. An 
effective public relations program must employ techniques ranging from broad-based traditional mass communication to highly individualized interpersonal communication. Moreover, the process of selecting media must be rationalized" (p. 463; italics in original).

However, some fear that the process of "rationalization" is not proceeding fast enough. Speaking of the "fad" of integrated marketing communication (IMC), Hutton (2001) observed that IMC "is little more than a confession that nonintegrated or disintegrated communications have been the norm in the past" (p. 209). The real debate should be about the "relationship between what might be termed integrated marketing and integrated communication" (p. 209). However, this debate was not being engaged because public relations was unilaterally ceding its turf to marketing, as "marketing scholars and practitioners are methodically redefining marketing as public relations" (p. 210).

The "disintegration" of public relations alarmed Hutton (2001). Other organizational functions were assimilating high-order public relations functions such as investor relations. This was not due to marketing imperialism, so much as it was due to the failure of public relations scholarship to "define itself and to develop sophisticated and progressive theory" (p. 213). In Hutton's view, the legitimacy of the public relations function was precarious. "There remains a need for public relations to define its intellectual and practical domain, especially vis-á-vis marketing, to regain control over its destiny" (p. 205).

Within the hierarchical tribe, the optimists and pessimists disagree on the soundness of the discipline's intellectual underpinnings. The ambitious projects of the hierarchical voice are far from completion. The hierarchical voice faces formidable cultural challenges. In particular, the CI voice objects that public relations practice is too situational, fluid, and emergent to be thoroughly rationalized. Despite these challenges, many hierarchical adherents remain optimistic, anticipating that the 21 st century will be the golden age of public relations (e.g., Seitel, 2001).

\section{The Al Voice}

AI is the refuge of the free spirit. As Adams (1995) put it, "This way of life is distinguished from the other four 'engaged' ways of life by its intellectual independence and lofty detachment" (pp. 201-202). For enlightenment to be attained, human nature must be liberated from attachment and dependency. AIs avoid coercive entanglements, especially coercive demands for "right thinking." Human relationships must have exit points; individuals must be able to withdraw from associations that become oppressive (Thompson, 1982). "To the extent that we are capable of detaching ourselves from the fray and rising above it, we are likely to appreciate the partiality of those below" (Adams, 1995, p. 201).

Cultural theory considers the AI culture to be rare (Thompson et al., 1990). However, Fiske's (1991) equality matching model showed how AI interdepen- 
dence is structured. An equality matching relationship maintains equality of input and reward (e.g., two couples trade babysitting services). In work settings, equality matching synchronizes the contributions of group members so that each works at the same rate (Fiske, 1991). Equality matching ensures that neither party accumulates long-term debt. This exchange minimizes long-term dependence and maintains mutual autonomy. To the extent that the AI culture participates in public relations discussions, it mainly seeks to preserve a public relations niche for cooperative and noncoercive relationships.

In politics, the Natural Law Party articulates the AI voice. Human problems "result from a narrowness of vision that fails to comprehend life's essential unity" (Hagelin, 2003). However, "with maximally expanded comprehension, individuals naturally behave in their own best long-term interests while promoting the interests of society as a whole-action fully aligned with natural law" (Hagelin, 2003). With proper enlightenment, the need for governmental regulation will diminish.

Is there a type of public relations that remains free from coercive entanglements? People who practice public relations as a part-time craft may represent this position (Leichty \& Springston, 1996). Some public relations partnerships have features similar to the AI model. In his study of executive conflict, Morrill (1995) found a work culture that he characterized as "silent hives." The social relationships in these partnership firms maximized professional autonomy, discretion, and equality. They also minimized overt expressions of conflict. In agency public relations, partners may share the costs of doing business (e.g., office costs), while each practitioner maintains his or her own accounts and independent areas of expertise. J. E. Grunig and Hunt's (1984) public information model contained elements of the AI voice. If information is a "neutral medium," one can function as a journalist in residence by responding to inquiries about the organization. In a more proactive form, one might put out information for people to use as they see fit. An AI representative might prefer the job title of "information specialist."

The AI perspective provides scholars with an important refuge. Dozier and Lauzen (2000) argued that the "intellectual domain requires a conscious uncoupling of intellectual agenda from the thoughts, actions and preoccupations of practitioners" (p. 4). They called on public relations scholars to sever their ties to the "invisible clients" who have focused public relations research agendas on organizational level questions. They argued that this prevented consideration of the unintended consequences of public relations programs. Although Dozier and Lauzen argued for more applications of critical theory, their plea to liberate the intellectual domain of public relations was consistent with the AI perspective.

For most people, the AI perspective represents a temporary stopping point. As Adams (1995) noted, "Adherents to the different engaged ways of life argue with each other with different premises, but often reserve a special contempt for philosophers who merely interpret" (p. 210). The AI framework encourages one to stand 
aloof from social life. Adams speculated that AI might "induce a resigned fatalism or provide the three activist ways of life with superior insight into the behavior of competing ideologies, an insight that they may seek to exploit in their own management of risk" (p. 202).

Culbertson (1989) maintained that practitioners must have a "breadth of perspective" to interpret management to publics and vice versa. However, White (1988) questioned whether public relations practitioners had such a comprehensive perspective. A practitioner's organizational position and role limits her vision. White concluded, "Theoretically, it is questionable that practitioners can develop the perspective they have claimed to offer" (p. 11). However, the AI perspective does not require superhuman intuition because the relational models are part of our social knowledge (Fiske, 1991). Perspective taking requires a clear memory to avoid cultural myopia. The CT perspective developed in this article employs the rationale of AI culture (Leichty \& Warner, 2001).

\section{The Cl Voice}

The CI voice is a powerful voice in the dominant public relations coalition. The CI voice celebrates public relations practice as a virtuoso performance (e.g., Budd, 1992b; Dilenschneider, 1990). CI culture cultivates the biography of the great person. Ivy Lee articulated this voice in the discipline's infancy.

Hiebert's (1966) historical biography of Lee captured the CI spirit. Hiebert wrote, "Lee was impressed by the important and newsworthy people. He made the most to cultivate his contacts with prominent men and then in making an impression with his own talents and personality" (p. 34). According to Hiebert, "Lee's respect for the great men of his time never waned" (p. 231). Lee chastised his associate Daniel Pierce by saying, "Dan, you spend too much time with unimportant people" (p. 234). Lee assiduously cultivated this network of influential people. Hiebert concluded that Lee "put himself squarely into the circle of his day. From his position he was able to win wide respect for the new profession of public relations" (p. 240).

Lee held his ground with the titans of industry as he promoted his mantra of informing the public. Hiebert (1996) noted that Lee was "one of the few men who could make millionaires wait for him" (p. 234). Lee maintained his professional independence. He tendered his resignation to John D. Rockefeller after only a year on his payroll. Explaining his decision to leave, Lee said, 'I' $m$ afraid I will become so conditioned to it all (i.e., the visible wealth) that in five years I'll be too timid to give you my real opinions for fear of losing my job" (p. 117). He explained that, in his own company, "I'll never be entirely dependent on anyone, and will be in a position to give advice no matter how unpalatable" (p. 117).

Lee was a 20th-century Renaissance Man. He had more than 10,000 books in his library and could quote verbatim from many hundreds of them. Hiebert (1966) wrote that Lee was most interested in "the spread of ideas in which he believed. In- 
deed his disregard for money bordered on improvidence" (p. 24). Lee had an eclectic interest "in the whole range of human relationships, trade, employee, industrial, government, community and international" (p. 44). In contrast to the specialized tasks of Hill's (1993) public relations, Lee sought intuitive solutions. Bernays characterized Lee's work as an "art" and labeled his own work as more "scientific" (Hiebert, 1966, p. 92).

Dilenschneider's (1990) bestseller, entitled Power and Influence: Mastering the Art of Persuasion, celebrated the vigorous individual asserting, negotiating, currying favors, telling stories, and building the power network. At the time, Dilenschneider was the CEO of Hill and Knowlton. He portrayed the great and influential person to be at the center of the network that made society move, shake, and progress. Public relations offered an exuberant and exciting life: the love of the chase and the art of the deal.

The chapter headings told the CI enthusiast how to perceive and organize the social environment. Time is precious, so one chapter explained, "How to Read the Wall Street Journal in Three Minutes." Another advised readers on how to develop "The Favor Bank." One must take credit for one's accomplishments.

Many managers feign modesty. ... They always say, "My people really deserve the credit." Don't believe them. If you want to be influential, you have to step forward without being pushy. You can't pretend you are less than you really are. Carefully and diplomatically, you must make sure that your influence is recognized. (Dilenschneider, 1990, p. 59)

He admonished readers to "tell stories as a teacher would. ... Influential people are supposed to live interesting lives. Fresh lively 'war stories' interweave you with important events and people. They prove your life is interesting" (Dilenschneider, 1990, p. 63).

Like Lee, Dilenscheider advised readers on how to build a power network. "Only involve yourself with projects that deliver recognizable impact. Being yet another volunteer for the Red Cross or the United Way may do your heart good, ... but it won't add any value to your power credentials" (Dilenschneider, 1990, p. 66). Executives were counseled to "grow your community involvements with your career. ... as the executive rises, society expects more, and it is expected he will involve himself at the highest-level of which he is capable" (p. 67).

The CI voice embraces what Brummet (1995) called the "scandalous rhetorics" that elevate application over theory and partisan interests over community interests. Partisan rhetoric enables ordinary people to participate in the debates of a democratic society. If your voice is marginalized, "one way to make sure to keep you there is to insist that you register your complaint using the logical argument and polite debate that prop up the established interests to begin with" (p. 24). In an era of knowledge explosion, expertise becomes increasingly 
narrow and hinders decision making. Brummet argued that disciplines like public relations must use narrative to reduce the complexity of public domain communications to manageable proportions.

The CI voice bristles at the hierarchical strictures of corporate public relations. Budd's (1992b) public relations textbook entitled Street Smart Public Relations targeted practitioners who

want to extricate themselves from the spaghetti-like quagmire of administration, standard operating procedures and lines of authority. If you want theoretical language and MBA formulas fleshing out your five-year plans, let me suggest any of the academic texts that flourish. The certitude of approach is impressive- but of course unrealistic. (Swift, 1992, p. 8)

In another venue, Budd (1992a) complained that bureaucratic corporate cultures were subverting public relations practice. He lamented, "Public relations managers themselves are quarantined from the daily combat of opinion making by staff — and staff is cushioned from accountability by specialization" (p. 29). He declared that public relations is "a unique profession. Because it deals with the unpredictable —opinions, attitudes, impressions - it has to be flexible, dynamic, instantaneous and exceptionally skilled" (p. 27). The dynamic environment of public relations meant that public relations "must be entrepreneurial-not bureaucratic! In attitudes, approach and activity" (p. 25).

Keen (1997) contrasted right-brain decision making combining intuition, instinct, and experience with linear left-brain processing. He recounted that his first retail sales analysis took him months to complete because his hierarchically oriented manager was "meticulous in his fact-based thinking and decision-making. He had to have hard data to analyze" (p. 35). Keen opined that public relations practitioners no longer conduct such in-depth analyses, because decision making now requires greater speed. He observed, "People in top management had a higher intuitive score than those in middle management positions. ... the ladder of success, the greater the use of intuition" (p. 36).

The CI camp dismisses the algorithmic pretensions of public relations theory. It prefers contingency theories that describe the practitioner's competence. In developing their version of contingency theory, Cancel, Cameron, Sallot, and Mitrook (1997) imagined a seasoned practitioner responding to a question of how she relates to publics. They presumed the practitioner would say, "It depends on a whole of lot things. First, you have to talk in terms of a specific public at a particular time. Then you must ask some questions" (p. 31). They concluded, "We argue that this fictional practitioner has thousands of counterparts in actual practice who offer a better, more subtle, and more sophisticated understanding of accommodation than what is to be found in the academic grove" (p. 32). 
The CI voice emphasizes the contextual variations of public relations. Public relations theory cannot encompass all of the unique niches that public relations contains. Moreover, the public relations environment is always changing. Theory lags behind practice and is often outmoded by the time it is developed. New professionals must have apprenticeships and practical experience to learn the ropes. You simply cannot learn public relations from a book.

This belief in flux and change appears in how the CI voice constructs the public relations implications of the Internet. Where the hierarchical voice projects that the Internet will be integrated with existing public relations practices (e.g., Greece, 2000), the CI voice declares that public relations needs to be reinvented to fit the world of the Internet. Gronstadt (2000) declared:

To them, the Internet offers just another message delivery tool, with limited and impatient audiences. This view is on par with the horse-and-buggy operator criticizing the Model-T Ford for being too loud. The Internet is not just a new medium; it's rapidly becoming a platform for all other media, and more. (p. 15)

In the end, the CI voice is not anxious about names or labels. Ivy Lee never selected one label to describe what he did, "confessing at the end of his life that even his own children did not know what to call him" (Hiebert, 1966, p. 6). The CI voice is more concerned with making things happen than it is with definitions and labels. $\mathrm{CI}$ culture exudes confidence about the future. It will be the best of times for those who are willing to learn and willing to grasp the rings of power.

\section{IMPLICATIONS FOR PUBLIC RELATIONS}

This analysis sought to demonstrate that the CT framework (Leichty \& Warner, 2001) also applies to discourse about public relations. Of course, many debates within public relations do not organize themselves around the CT presented here. Many debates concern issues where scholars and practitioners share the same CT. Such debates often focus on the best means to accomplish agreed-on ends or about the adequacy of current attempts to build the discipline's knowledge base (e.g., Hutton, 2001). These debates may seldom articulate their underlying cultural premises.

It is also true that a person may shift in her cultural allegiances over time. In an earlier version of this article, I classified work on the two-way symmetrical model (e.g., J. E. Grunig, 1992) as an exemplar of the hierarchical topoi. I refrained from classifying this important work in this article, because recent versions of this work (e.g., J. E. Grunig, 2001) have overtly shifted to egalitarian topoi. This shift came in response to egalitarian criticisms of the two-way symmetrical framework (e.g., Karlberg, 1996). 
It is also true that the same person may express different $\mathrm{CT}$ at the same point in time, especially if the speaker crosses domains. Adams (1995) reminded us that "Our cultural filters must cope with a cacophony of competing and conflicting messages. ... But often it appears that our lives are compartmentalized in ways that permit us to hold beliefs that are mutually inconsistent" (p. 202). However, even this seeming inconsistency may be reconciled if one admits that different models of relationships apply to different parts of the social world (i.e., Fiske, 1991).

Shifts in CT across time and domains do not undermine the CT framework. Indeed, the CT system can make these transitions intelligible. The CT system identifies the limited number of rhetorical options that a speaker has for arguing for the correctness of social practices. The CT perspective identifies likely points of opposition and engagement between the different cultural camps. The twists and turns of cultural discourse can be complex, but a CT perspective allows one to anticipate and interpret these constructions (Leichty \& Warner, 2001).

Future work will determine how useful the CT framework is for interpreting specific issues within public relations. Several projects are worthy of mention. The CT framework could identify cases of “toxic public relations discourse.” Ellis' (1998) historical critique of the dark side of egalitarian political discourse is an exemplar of how such work could proceed. Rhetorical critiques could identify "cultural pathologies" that emerge when a particular cultural voice becomes hegemonic.

Future research should also investigate how each cultural tribe constructs public relations's history. This could include an analysis of how each cultural camp constructs its cultural adversaries to advance its own proposals for the discipline (Leichty, 2001; Pieczka \& L'Etang, 2001). Such analyses also could chart how public relations discourse has shifted from one set of cultural presuppositions to another. For instance, a "cultural history" of how the two-way symmetrical model of public relations has evolved is certainly in order.

We also need to determine what kinds of cultural diversity enhance public relations practice. In addition to ethnic diversity (e.g., Banks, 2000), cultural theory asserts that cultural diversity is a necessity for democratic life (Thompson et al., 1990). What requisite forms of cultural diversity neutralize the hegemonic impulses of each cultural voice? What communication practices sustain a needed level of cultural diversity within the discipline? What kind of cultural diversity within public relations preserves and expands the stock of social capital available in democratic societies (Putnam, 2000)?

In this light, we can reframe the ongoing squabble about the right way to define public relations. Of culture, Schwartz and Thompson (1990) wrote, "It is by our never ending contentions that it organizes itself" (p. 71). The same is true of public relations. The diversity of voices is not a sad commentary on the state of public relations; indeed, it is a starting point for characterizing public relations theory and practice. 


\section{REFERENCES}

Adams, J. (1995). Risk. London: University College London Press.

Alinsky, S. D. (1971). Rules for radicals: A practical primer for realistic radicals. New York: Vintage.

Banks, S. P. (2000). Multicultural public relations: A social interpretive approach (2nd ed.). Ames: Iowa State University Press.

Beder, S. (1998). Public relations role in manufacturing artificial grass-roots coalitions. Public Relations Quarterly, 43(2), 20-23.

Berger, B. K. (1999). The Halcion affair: Public relations and the construction of an ideological world-view. Journal of Public Relations Research, 11, 185-203.

Bernays, E. (1952). Public relations. Norman: University of Oklahoma Press.

Bernays, E. (1955). The theory and practice of public relations: A resume. In E. Bernays (Ed.), The engineering of consent (pp. 1-25). Norman: University of Oklahoma Press.

Botan, C. H. (1989). Theory development in public relations. In C. Botan \& V. Hazleton (Eds.), Public relations theory (pp. 99-110). Hillsdale, NJ: Lawrence Erlbaum Associates, Inc.

Broom, G. M., \& Dozier, D. (1986). Advancement for public relations role models. Public Relations Review, 7(1), 37-56.

Brummet, B. (1995). Scandalous rhetorics. In W. N. Elwood (Ed.), Public relations inquiry as rhetorical criticism: Case studies in corporate discourse and social influence (pp. 13-26). Westport, CT: Praeger.

Budd, J. F. (1992a). Bureaucratic trend threatens PR's future. Communication World, 9(6), 24-29.

Budd, J. F. (1992b). Street smart public relations. Lakeville, CT: Turtle.

Cancel, A., Cameron, G., Sallot, L., \& Mitrook, M. (1997). It depends: A contingency theory of accommodation in public relations. Journal of Public Relations Research, 9, 31-63.

Coombs, W. T. (1999). Ongoing crisis communication: Planning, managing, and responding. Thousand Oaks, CA: Sage.

Creedon, P. J. (1993). Acknowledging the infrasystem: A critical feminist analysis of systems theory. Public Relations Review, 19, 157-166.

Cropp, F., \& Pincus, J. D. (2001). The mystery of public relations: Unraveling its past, unmasking its future. In R. Heath (Ed.), Handbook of public relations (pp. 189-203). Thousand Oaks, CA: Sage.

Culbertson, H. M. (1989). Breadth of perspective: An important concept for public relations. In J. E. Grunig \& L. A. Grunig (Eds.), Public relations research annual (Vol. 1, pp. 3-26). Hillsdale, NJ: Lawrence Erlbaum Associates, Inc.

Cutlip, S. C. (1994). Public relations history: From the 17th to the 20th century. The antecedents. Hillsdale, NJ: Lawrence Erlbaum Associates, Inc.

Dilenschneider, R. L. (1990). Power and influence: Mastering the art of persuasion. New York: Prentice Hall.

Douglas, M. (1996). Thought styles. London: Sage.

Douglas, M. (1997). The depolitization of risk. In R. J. Ellis \& M. Thompson (Eds.), Culture matters (pp. 121-132). Boulder, CO: Westview.

Douglas, M., \& Ney, S. (1998). Missing persons: A critique of the social sciences. Berkeley: University of California Press.

Douglas, M., \& Wildavsky, A. (1982). Risk and culture. Berkeley: University of California Press.

Dozier, D. (1992). The organizational roles of communications and public relations practitioners. In J. E. Grunig (Ed.), Excellence in public relations and communication management (pp. 327-356). Hillsdale, NJ: Lawrence Erlbaum Associates, Inc.

Dozier, D., \& Lauzen, M. (2000). Liberating the intellectual domain from the practice: Public relations, activism and the role of the scholar. Journal of Public Relations Research, 12, 3-22.

Ellis, R. J. (1998). The dark side of the left: Illiberal egalitarianism in America. Lawrence: University of Kansas Press. 
Ewen, S. (1996). PR: The social history of spin. New York: Basic Books.

Fiske, A. (1991). Structures of social life: The four elementary forms of human relations. New York: Free Press.

Fiske, A., \& Tetlock, P. E. (1997). Taboo trade-offs: Reactions to transactions that transgress the spheres of justice. Political Psychology, 18, 255-297.

Fulwood, C. (1996). Alar report right from the start, but you'd never know it. Public Relations Quarterly, 41(2), 9-12.

Gandy, O. (1992). Public relations and public policy: The structuration of dominance in the information age. In E. Toth \& R. Heath (Eds.), Rhetorical and critical approaches to public relations (pp. 131-163). Hillsdale, NJ: Lawrence Erlbaum Associates, Inc.

Greece, M. (2000). Public relations truths in a Dot-com age. The Public Relations Strategist, 6(1), 17-19.

Gronstadt, A. (2000). Integrating communication on Internet time. The Public Relations Strategist, $6(1), 13-15$.

Grunig, J. E. (1992). Excellence in public relations and communication management. Hillsdale, NJ: Lawrence Erlbaum Associates, Inc.

Grunig, J. E. (2001). Two-way symmetrical public relations: Past, present and future. In R. Heath (Ed.), Handbook of public relations (pp. 31-50). Newbury Park, CA: Sage.

Grunig, J. E., \& Hunt, T. (1984). Managing public relations. New York: Holt, Rinehart, \& Winston.

Grunig, L. A., \& Toth, E. (2001). Women in public relations: How gender influences practice. New York: Guilford.

Grunig, L. A., Toth, E. L., \& Hon, L. C. (2000). Feminist values in public relations. Journal of Public Relations Research, 12, 49-68.

Hagelin, J. (2003). Creating ideal administration: Harnessing natural law to achieve a self-governing nation. Retrieved from www.natural-law.org/ideal-administration/index.html

Hallahan, K. (2001). Strategic media planning: Toward an integrated public relations media model. In R. Heath (Ed.), Handbook of public relations (pp. 461-470). Thousand Oaks, CA: Sage.

Hiebert, R. E. (1966). Courtier to the crowd: The story of Ivy Lee and the development of public relations. Ames: Iowa State University Press.

Hill, J. W. (1993). The making of a public relations man. Lincolnwood, IL: NTC Publishing.

Hirschman, A. O. (1991). The rhetoric of reaction: Perversity, futility and jeopardy. Cambridge, MA: Belknap Press.

Holt, T. (1995). Consumer groups and trial lawyers: An unholy alliance. Public Relations Strategist, $1(3), 34-39$.

Holthauzen, D. R. (2000). Postmodern values in public relations. Journal of Public Relations Research, $12,93-114$.

Hon, L. C. (1995). Toward a feminist theory of public relations. Journal of Public Relations Research, 7, 27-81.

Hon, L. C. (1997). To redeem the "Soul of America:" Public relations and the civil rights movement. Journal of Public Relations Research, 9, 163-212.

Hon, L. C., \& Brunner, B. (2000). Diversity issues and public relations. Journal of Public Relations Research, 12, 309-340.

Hutton, J. (2001). Defining the relationship between public relations and marketing. In R. Heath (Ed.), Handbook of public relations (pp. 205-214). Thousand Oaks, CA: Sage.

Karlberg, M. (1996). Remembering the public in public relations research: From theoretical to operational symmetry. Journal of Public Relations Research, 8, 263-278.

Keen, T. R. (1997). Intuitive decision-making. The Public Relations Strategist, 3(2), 35-37.

Kern-Foxworth, M. (1992). Martin Luther King Jr.: Minister, civil rights activist, and public opinion leader. Public Relations Review, 18, 287-296.

Kern-Foxworth, M. (1994). Assessing the managerial roles of black female public relations practitioners using individual and organizational discriminants. Journal of Black Studies, 24, 416-434. 
Kohn, S. (2000). The nasty truth about high-tech public relations. The Public Relations Strategist, 6(2), 27-30.

Kotler, P. (1994). Marketing management: Analysis, planning, implementation and control (8th ed.). Upper Saddle River, NJ: Prentice Hall.

Kruckeberg, D., \& Starck, K. (1988). Public relations and community: A reconstructed theory. New York: Praeger.

Leeper, R. (2001). In search of a metatheory for public relations: An argument for communitarianism. In R. Heath (Ed.), Handbook of public relations (pp. 93-104). Newbury Park, CA: Sage.

Leichty, G. (2001, November). The dark side of public relations. Paper presented at the annual meeting of the National Communication Association, Atlanta, GA.

Leichty, G., \& Springston, J. (1996). Elaborating public relations roles. Journalism Quarterly, 73, 467-477.

Leichty, G., \& Warner, E. (2001). Cultural topoi. In R. Heath (Ed.), Handbook of public relations (pp. 61-74). Newbury Park, CA: Sage.

Lesly, P. (1984). Overcoming opposition: A survival manual for executives. Englewood Cliffs, NJ: Prentice Hall.

Lesly, P. (1991). Coping with opposition groups. Public Relations Review, 18, 325-334.

Lesly, P. (1996). The Balkanizing of public relations. The Public Relations Strategist, 2(3), 41-44.

Lockhart, C. (1997). Political culture and political change. In R. Ellis \& M. Thompson (Eds.), Culture matters (pp. 91-104). Boulder, CO: Westview.

Meyer, G. J. (1996). Scars from the public relations job wars. The Public Relations Strategist, 2(2), $15-19$.

Miller, K. S. (1999). Public relations in film and fiction: 1930-1995. Journal of Public Relations Research, 11, 3-28.

Morrill, C. (1995). The executive way: Conflict management in corporations. Chicago: University of Chicago Press.

Olaniran, B., \& Williams, D. (2001). Anticipatory model of crisis management. In R. Heath (Ed.), Handbook of public relations (pp. 487-500). Thousand Oaks, CA: Sage.

Peppers, D., \& Rogers, M. (1997). Enterprise one to one: Tools for competing in the interactive age. New York: Doubleday.

Peters, J. (1999). Public journalism and democratic theory: Four challenges. In T. Glasser (Ed.), The idea of public journalism (pp. 99-117). New York: Guilford.

Pieczka, M., \& L'Etang, J. (2001). Public relations and the question of professionalization. In R. Heath (Ed.), Handbook of public relations (pp. 223-236). Thousand Oaks, CA: Sage.

Putnam, R. (2000). Bowling alone: The collapse and revival of American community. New York: Simon \& Schuster.

Rampton, S., \& Stauber, J. (2001). Trust us, we're experts! How industry manipulates science and gambles with your future. New York: Tarcher/Putnam.

Rein, I., Kotler, P., \& Stoller, M. (1997). High visibility: The making and marketing of professionals into celebrities. Chicago: NTC Books.

Schwartz, M., \& Thompson, M. (1990). Divided we stand: Redefining politics, technology and social choice. Philadelphia: University of Pennsylvania Press.

Seitel, F. (1998). Reflections of an American guru: An afternoon with Peter Drucker. The Public Relations Strategist, 4(3), 8-15.

Seitel, F. (2000). Relax Mr. Stauber, public relations ain't that dangerous. The Public Relations Strategist, 6(2), 35, 37, 39.

Seitel, F. (2001). The practice of public relations (8th ed.). Upper Saddle River, NJ: Prentice Hall.

Smith, M. F. (1997, November). Public relations from the "Bottom up:" Toward a more inclusive view of public relations. Paper presented at the annual meeting of the National Communication Convention, Chicago. 
Smith, M. F., \& Ferguson, D. P. (2001). Activism. In R. Heath (Ed.), Handbook of public relations (pp. 291-300). Thousand Oaks, CA: Sage.

Sriramesh, K. (1996). Power distance and public relations: An ethnographic study of Southern Indian organizations. In H. Culbertson \& N. Chen (Eds.), International public relations: A comparative analysis (pp. 171-190). Newbury Park, CA: Sage.

Sriramesh, K., Kim, Y., \& Takasaki, M. (1999). Public relations in three Asian cultures: An analysis. Journal of Public Relations Research, 11, 271-292.

Stauber, J., \& Rampton, S. (1995). Toxic sludge is good for you: Lies, damn lies and the public relations industry. Monroe, ME: Common Courage Press.

Swift, P. (1992). Debunking conventional wisdom. Public Relations Quarterly, 37(3), 7-8.

Taylor, M., \& Kent, M. L. (1999). Challenging the assumptions of international public relations. Public Relations Review, 25, 131-144.

Tetlock, P. (2000). Cognitive biases and organizational correctives: Do both disease and cure depend upon the politics of the beholder? Administrative Science Quarterly, 45, 293-326.

Tetlock, P., Kristel, O. V., Elson, S. B., Green, M. C., \& Lerner, J. S. (2000). The psychology of the unthinkable: Taboo tradeoffs, forbidden base rates, and heretical counterfactuals. Journal of Personality and Social Psychology, 78, 853-970.

Thompson, M. (1982). The problem of the center: An autonomous cosmology. In M. Douglas (Ed.), Essays in the sociology of perception (pp. 302-328). London: Routledge \& Kegan Paul.

Thompson, M., Ellis, R., \& Wildavsky, A. (1990). Cultural theory. Boulder, CO: Westview.

Toth, E. L. (2001). How feminist theory advanced the practice of public relations. In R. Heath (Ed.), Handbook of public relations (pp. 237-246). Thousand Oaks, CA: Sage.

Turk, J. (1996). Romania from publicitate past to public relations future. In H. Culbertson \& N. Chen (Eds.), International public relations: A comparative analysis (pp. 341-348). Newbury Park, CA: Sage.

White, J. (1988). The vantage point problem of public relations. Public Relations Review, 14(2), 3-11.

Wildavsky, A. (1987). Choosing preferences by constructing institutions: A cultural theory of preference formation. American Political Science Review, 81, 3-21. 
Copyright $\odot 2003$ EBSCO Publishing 